\title{
Injerto libre braquial medial
}

\author{
Free medial arm graft
}

\author{
P. Martos Díaz1, F.J. Rodríguez Campo², R. González García', V. Escorial², S. Guillermo², \\ F.J. Díaz González ${ }^{3}$
}

Resumen: Introducción. Entre las reconstrucciones de defectos titulares de cabeza y cuello, el injerto libre microvascularizado braquial medial no ha adquirido mucha popularidad debido a las variaciones anatómicas que se reflejan en la vascularización de éste. Nuestro objetivo es realizar una descripción de la anatomía y técnica quirúrgica, así como una revisión de la literatura describiendo las ventajas y desventajas de este tipo de injerto.

Material y método. Presentamos el caso de una paciente con carcinoma epidermoide de mucosa yugal izquierda con afectación ganglionar ipsilateral. Se procedió a su resección con márgenes más disección cervical funcional. La reconstrucción del defecto se llevó a cabo mediante un injerto libre microvascularizado braquial medial de brazo izquierdo.

Discusión. Pensamos que el injerto libre braquial medial de brazo se trata de una opción más segura a la hora de la reconstrucción de defectos cervicofaciales, aportando una serie de ventajas entre las que destacan: no sacrificio de una arteria terminal, cierre primario de la zona donante, mínimo defecto estético, y poseer una piel fina, elástica y sin vello.

Palabras clave: Colgajo branquial medial; Arteria colateral superior cubital.

Recibido: 17.10.05

Aceptado: 23.03 .07
Abstract: Introduction. Free medial microvascularized arm grafts have not become very popular for the reconstruction of head and neck defects due to anatomic variations in their vascularization. Our objective was to describe the anatomy and surgical technique and to review the literature on the advantages and disadvantages of free medial arm grafts.

Material and methods. We report the case of a patient with squamous cell carcinoma of the left jugal mucosa with same-side lymph node involvement. The tumor was resected with margins and a functional cervical dissection was performed. The defect was reconstructed using a free medial microvascularized graft from the left arm.

Discussion. We believe that free medial arm grafts are a safer option for the reconstruction of cervicofacial defects and that they offer advantages, among which can be highlighted: not sacrificing a terminal artery, primary closure of the donor zone, minimal esthetic defect, and yielding fine, elastic, hairless skin.

Key words: Medial arm flap; Superior ulnar collateral artery.

\footnotetext{
1 Médico Residente.

2 Medico Adjunto.

3. Jefe de Servicio. Servicio de Cirugía Oral y Maxilofacial

Hospital Universitario de la Princesa. Madrid, España.
}

\section{Correspondencia:}

Pedro Luis Martos Díaz.

Hospital de la Princesa.

Departamento de Cirugía Maxilofacial.

C/ Diego de León Nº 62, 28006, Madrid, España.

Email: plmartos@mixmail.com 


\section{Introducción}

Son muchos los tipos de reconstrucción empleados en nuestros días para cubrir defectos de los tejidos blandos a nivel cervicofacial, sobre todo en el ámbito de resecciones oncológicas o para dar cobertura eficaz tras heridas postraumáticas con importante pérdida tisular.

Entre los injertos libres microvascularizados, el más extendido en la actualidad en el campo de la cirugía maxilofacial, es el injerto libre antebraquial, que ha ido adquiriendo popularidad gracias a una serie de ventajas, entre las que se encuentran: tener una anatomía constante, gran seguridad, flexibilidad en su diseño, y tener la opción de trabajar en dos campos a la vez, con dos equipos diferentes. ${ }^{1}$

En la elección del método reconstructivo, influyen características del propio injerto (características de la piel, grosor, longitud del pedículo, etc) y de la zona receptora (defecto intraoral, extraoral, o mixto, con o sin afectación ósea, etc).

En este sentido, el colgajo medial de brazo constituye una opción más para reconstrucciones de defectos tisulares en la región cervicofacial. Entre sus ventajas se encuentran: ser una zona con poco vello, poseer una piel relativamente fina y elástica, buena cicatrización de la zona donante, tener una localización poco visible, permitir un cierre directo y que su pedículo no conlleva la anulación de una arteria terminal.

En este artículo, se pretende hacer una breve descripción de la anatomía y técnica quirúrgica para la realización del colgajo medial de brazo, aportando un nuevo caso clínico a la literatura y haciendo una revisión de ésta.

\section{Descripción anatómica}

La piel de la parte medial del brazo, está irrigada por ramas de la arteria braquial, rama a su vez de la arteria axilar. A nivel de la mitad proximal del brazo, la arteria braquial da lugar a la arteria braquial profunda y en la mitad distal, a la arteria colateral cubital superficial (ACCS). Con mucha menos frecuencia, la AACS puede partir de la braquial profunda. Por otro lado, la arteria braquial, también puede dar ramas cutáneas directas, y ramos musculocutáneos que de forma variable contribuyen a la irrigación de esta zona medial del brazo. En cualquiera de los casos, siempre se demuestra una rama principal con un calibre superior al resto y que la mayor parte de las veces, será la ACCS, con una frecuencia que varía según los autores entre el 80 al 100\%.2-5

En la anatomía de superficie, la ACCS se origina aproximadamente a 4-6 cm distal a la inserción del músculo pectoral en el húmero, dirigiéndose por la región medial del brazo hasta $3-4 \mathrm{~cm}$ proximal a la epitróclea. Durante este trayecto, se acompaña de sus dos venas concomitantes, y va dando ramos cutáneos para la vascularización de la piel. La longitud total del pedículo oscila entre 5$8 \mathrm{~cm}$, y el diámetro entre 1,3-1,6 mm. ${ }^{4,5}$

\section{Técnica quirúrgica}

El paciente debe ser colocado en posición supina, con el brazo en supinación y con una abducción de $90^{\circ}$. El codo puede flexionarse también $90^{\circ}$ (Fig. 1).

\section{Introduction}

Many reconstructive techniques are now used to cover softtissue defects of the head and neck, particularly within the context of oncological resections or the repair of traumatic wounds with major tissue loss.

Among the free microvascularized grafts, the graft most widely used now in maxillofacial surgery is the free lower arm graft. This graft has become popular due to a series of advantages, including consistent anatomy, safety, design flexibility, and the feasibility of working simultaneously in two fields with two different teams.?

The choice of reconstructive method is influenced by the characteristics of the graft (skin characteristics, thickness, pedicle length, etc.) and receptor areas (intraoral, extraoral or mixed defect, presence or absence of osseous involvement, etc).

The medial arm graft is one of the options for repairing tissue defects in the cervicofacial region. Its advantages include: little hair, relatively fine and elastic skin, good donor zone healing, a location that is not very visible, permitting direct closure and a pedicle that does not contain a terminal artery.

In this article, we briefly describe the anatomy and surgical technique for preparing a medial arm flap. We report a new clinical case and review the literature.

\section{Anatomic description}

The blood supply to the skin of the medial part of the arm comes from branches of the brachial artery, a branch of the axillary artery. The brachial artery emits the deep brachial artery in the upper arm and the superficial collateral ulnar artery (SCUA) in the lower arm. Much less frequently, the SCUA branches from the deep brachial artery. The brachial artery can also emit direct cutaneous and musculocutaneous branches that contribute variably to the blood supply of the medial arm. In any case, a main branch of greater caliber than the others is always found and it is generally the SCUA, with a frequency of 80 to $100 \%$ depending on the author. ${ }^{2-5}$

In the surface anatomy, the SCUA originates approximately 4-6 cm distal to the insertion of the pectoral muscle on the humerus. It passes through the medial part of the arm to a point to $3-4 \mathrm{~cm}$ above the epitrochlea. The artery is accompanied in this trajectory by its two concomitant veins and it cutaneous branches that vascularize the skin. Overall pedicle length is 5 $8 \mathrm{~cm}$ and pedicle diameter is 1.3-1.6 mm.4,5

\section{Surgical technique}

The patient is placed in supine position with the arm supinated and abducted $90^{\circ}$. The elbow may be flexed $90^{\circ}$ (Fig. 1).

The axis of the flap is a straight line drawn from the medial axilla to the epitrochlea. The lower edge of the skin flap is located $3-4 \mathrm{~cm}$ from the epitrochlea and the upper edge depends 
A continuación, se traza el eje del colgajo, realizando una línea recta desde la región medial de la axila hasta la epitróclea. El límite inferior de la paleta cutánea se situará a 3-4 cm de la epitróclea, y el superior, dependiendo de la longitud que se precise, quedando siempre inferior a la axila. En cuanto al límite anterior, también dependerá de la superficie necesaria para el defecto a cubrir, localizándose más o menos a unos 3 ó $4 \mathrm{~cm}$ del eje trazado. La anchura total del colgajo, no debe superar los $8 \mathrm{~cm}$ para lograr un cierre directo. ${ }^{5}$

A continuación se incide la piel por el borde anterior, y mediante disección del tejido subcutáneo, antes de llegar a la fascia del bíceps braquial, se localiza y diseca la vena basílica. Se prosigue la disección, tratando de localizar más profundamente $y$ anterior a la vena el nervio mediano (Fig. 2). Previo a la localización del tronco principal del nervio mediano, se observarán algunos ramos nerviosos cutáneos que pueden ser preservados en caso de que no incomoden en gran parte la disección.

Una vez localizado el nervio mediano, se procederá a realizar la incisión posterior, comenzando por su parte más inferior. Subfascialmente se procede a la elevación del colgajo hasta localizar el nervio cubital, que debido a su calibre, no entraña un gran problema.

Mediante una disección delicada, junto al nervio cubital, se localiza el pedículo del injerto, formado por la arteria y las venas colaterales cubital superficial. En caso de que el diámetro de la vena sea demasiado pequeño, el colgajo podrá tomar como componente venoso a la vena basílica, constituyendo ésta la primera opción en la mayoría de los casos.

A lo largo de la disección, es posible encontrarnos con alguna rama arterial septocutánea de suficiente calibre, la cual debe respetarse y tenerla presente como posible componente del pedículo en caso de que la ACCS tenga un calibre menor.

Una vez extraído el injerto, se procederá a la realización de un cierre directo de la piel, la cual presenta una elasticidad suficiente para ello.

\section{Caso clínico}

Paciente de 58 años de edad con antecedentes de trombosis venosa en MMII. Resto sin interés. Presentaba una lesión ulcerada a nivel de la mucosa yugal izquierda de aproximadamente $3 \mathrm{~cm}$ de diámetro mayor compatible con carcinoma epidermoide (Fig. 3). Se palpaba a su vez una adenopatía de $2 \mathrm{~cm}$ de diámetro en nivel I cervical.

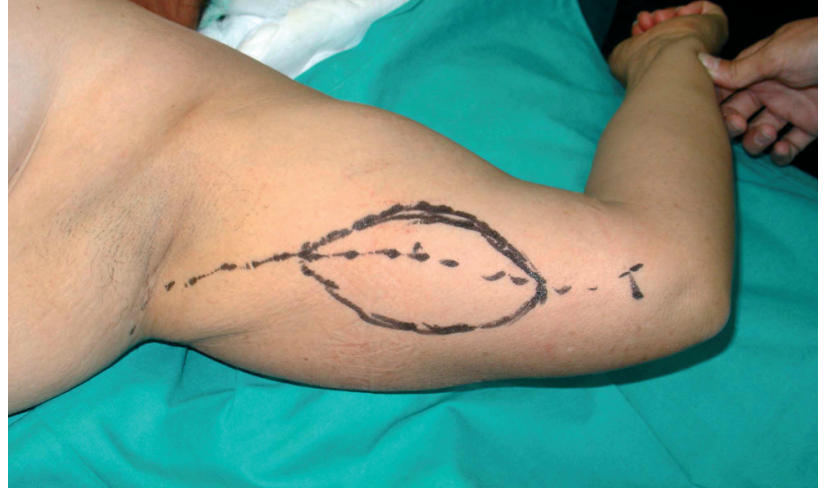

Figura 1. Diseño del colgajo.

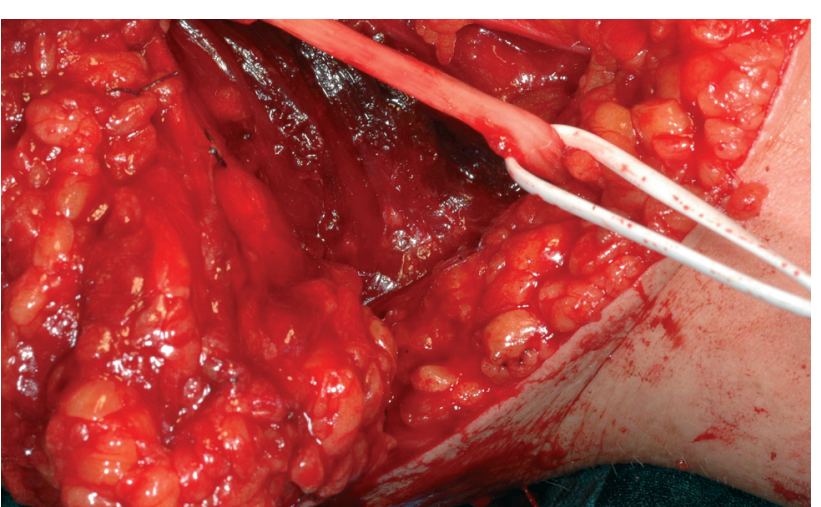

Figura 2. Nervio mediano

Figure 2. Median nerve. on the length needed, although it is always below the axilla. The anterior edge depends on the surface area required to cover the defect and is located about 3 or 4 $\mathrm{cm}$ from the axis. Total flap width should not exceed $8 \mathrm{~cm}$ for direct closure. 5

An incision is made in the skin on the anterior edge of the flap and the subcutaneous tissue is dissected. Before reaching the fascia of the brachial biceps, the basilic vein is located and dissected. Dissection continues and the median nerve is located deeper and anterior to the vein (Fig. 3). Prior to the location of the main trunk of the median nerve, cutaneous nerve branches will be visible, which may be preserved if they do not complicate dissection.

When the median nerve is located, the posterior incision is made, beginning from the lowest point. The flap is lifted subfascially until the ulnar nerve is located. This is not difficult because of its caliber.

A meticulous dissection is performed along the ulnar nerve and the graft pedicle, formed by the artery and the superficial collateral ulnar veins, is located. If the diameter of the vein is too small, the basilica vein can be used as the venous component of the flap. In most cases this is the first option.

Septocutaneous arterial branches of sufficient caliber may be found throughout the dissection. These branches must be conserved and reserved as a possible pedicle component if the caliber of the SCUA is smaller. Once the graft is lifted, the skin, which is sufficiently elastic, is closed directly.

\section{Clinical case}

The 58-year-old patient had a history of venous thrombosis of the lower limbs and no other findings of interest. The patient presented an ulcerated lesion of the left jugal mucosa that measured approximately $3 \mathrm{~cm}$ in diameter and was consistent with squamous cell carcinoma (Fig. 2). A lymph node $2 \mathrm{~cm}$ in diameter was palpated at cervical level $I$.

We performed surgery and resected the tumor with a safety margin and unilateral functional cervical dissection. The defect 
Se realiza intervención quirúrgica, procediéndose a la resección de la lesión tumoral con margen de seguridad y disección cervical funcional unilateral. La reconstrucción del defecto se realiza mediante injerto braquial medial del brazo izquierdo.

Como pedículo del colgajo se tomó la ACCS, que se anastomosó con la arteria facial, y el tronco venoso tirolinguofacial (TVTLF), que se unió a una de las venas concomitantes de la ACCS, al no refluir sangre por la vena basílica (Fig. 4).

La longitud del pedículo fue de unos $6 \mathrm{~cm}$, el diámetro de la arteria, de 1,5 $\mathrm{mm}$ y el de la vena, de $1 \mathrm{~mm}$.

El defecto intraoral quedó cubierto en su totalidad, aportando además suficiente volumen (Fig. 5), y el cierre de la piel del brazo se realizó de forma directa (Fig. 6) sin precisar la necesidad de un injerto libre.

Se procedió al alta de la paciente a los 10 días de la intervención contemplándose la correcta viabilidad del injerto.

\section{Discusión}

Fueron Daniel y cols. en 1975, ${ }^{6}$ quienes estudiaron primero el colgajo medial de brazo. Describieron la vascularización de éste mediante la disección de 16 cadáveres. Indicaron que dicha vascularización estaba basada en ramos perforantes cutáneos que provenían de la ACCS. Desde entonces, no han sido muchas las publicaciones en la literatura a cerca de este tipo de colgajo, observando a través de ésta, cierto rechazo a su uso, debido principalmente a las diversas variaciones encontradas en cuanto a la anatomía de esta parte medial del brazo.

Dolman y cols. ${ }^{2}$ publican en 1979

la ausencia de la ACCS en un $20 \%$ de las 20 disecciones sobre cadáver realizadas, refiriendo la imposibilidad de realizar el colgajo medial de brazo en caso de que la citada arteria estuviera ausente.

En 1981, Matloub y cols.7 demuestran mediante la disección de 36 cadáveres 5 tipos diferentes de irrigación a nivel de la región media del brazo.

En 1987, Breidenbach y cols. ${ }^{3}$ mediante la disección de 20 cadáveres, observan que la irrigación de la región medial del brazo se lleva a cabo mediante ramas cutáneas que parten en un $65 \%$ de la ACCS, en un $20 \%$ de la arteria braquial, y de ambas en el $15 \%$ de los casos.

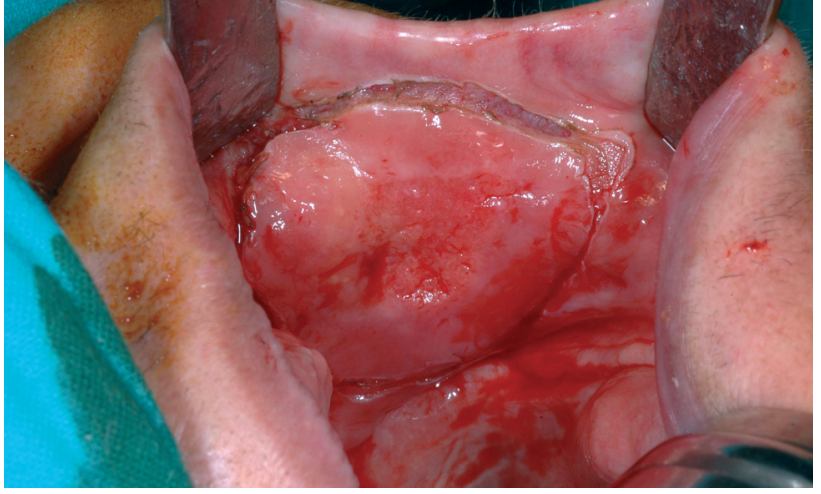

Figura 3. Resección de la lesión.

Figure 3. Resection of the lesion.

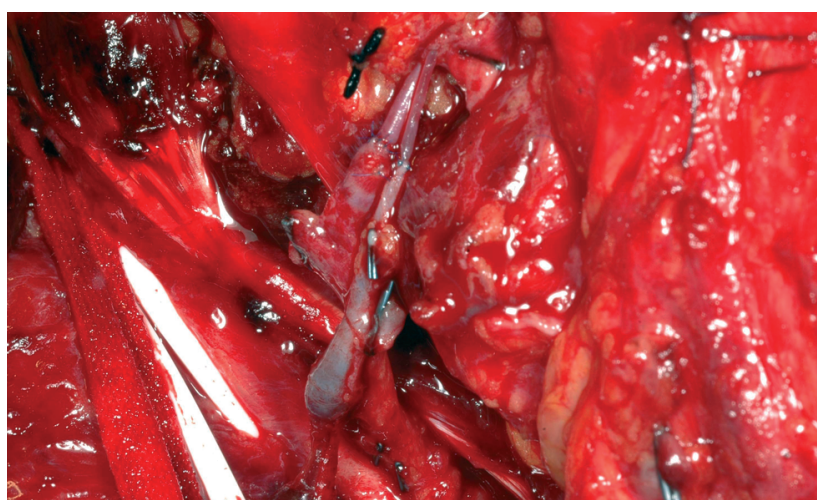

Figura 4. Suturas microquirúrgicas.

Figure 4. Microsurgical sutures.

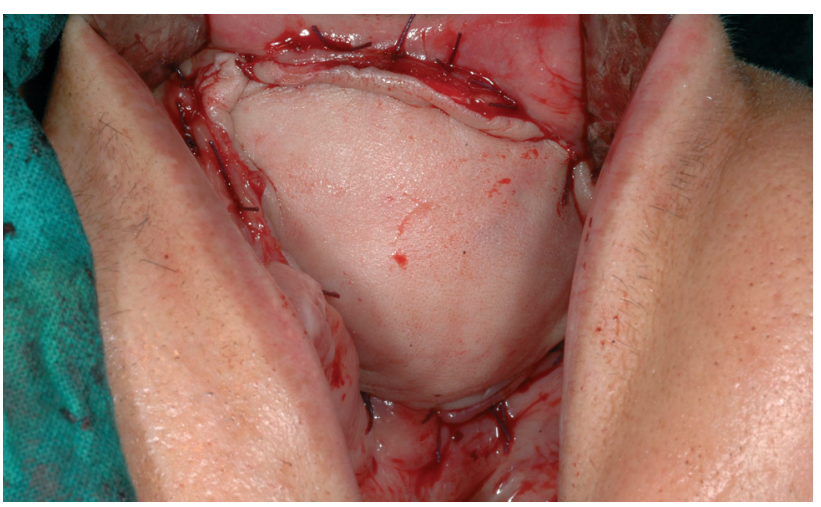

Figura 5. Colgajo en posición.

Figure 5. Flap in definite location. was reconstructed with a medial graft of the left arm. The flap pedicle used contained the SCUA, which was anastomosed to the facial artery. The thyro-linguo-facial venous trunk (TLFVT) was anastomosed to one of the concomitant veins of the SCUA because there was no retrograde blood flow through the basilic vein (Fig. 4).

Pedicle length was about 6 $\mathrm{cm}$, artery diameter, $1.5 \mathrm{~mm}$, and venous diameter, $1 \mathrm{~mm}$ The intraoral defect was covered completely with sufficient volume (Fig. 5). The skin of the arm was closed directly (Fig. 6) without need for a free graft.

The patient was released 10 days after the intervention and the viability of the graft was correct.

\section{Discussion}

Daniel et al. ${ }^{6}$ first studied the medial arm flap in 1975. They described the flap vascularization based on the dissection of 16 cadavers. The indicated that the vascularization is based on perforating cutaneous branches emitted by the SCUA. There have not been many publications since then on medial arm flaps. It is observed that there is a certain reluctance to use this flap, due mainly to the many variations found in the anatomy of the medial arm.

Dolman et al. ${ }^{2}$ in 1979 reported the absence of SCUA in $20 \%$ of 20 dissections of cadavers performed, noting the impossibility of preparing a medial arm flap if this artery is absent.

In 1981, Matloub et al.7 demonstrated five different types of blood supply to the middle arm region by dissecting 36 cadavers.

In 1987, Breidenbach et al. ${ }^{3}$ observed, in the dissection of 20 cadavers, that the blood supply to the medial region of the arm is conducted in $65 \%$ by cutaneous branches of the SCUA, in $20 \%$ by the brachial artery, and in $15 \%$ of cases, by both. 
En el paciente que describimos, no llegamos a contemplar la existencia de ramos cutáneos directos, viéndose que el vaso de diámetro predominante era la ACCS, de la que partían pequeños ramos hacia el tejido subcutáneo y piel.

En 1992 Matloub y cols. ${ }^{4}$ mediante la disección de 40 cadáveres, concluyen que la perfusión de la región medial del brazo, se lleva a cabo por una combinación de vasos que se originan a lo largo del curso de la arteria braquial. De estos vasos, siempre se observa uno de ellos con un calibre mayor de $1 \mathrm{~mm}$, y

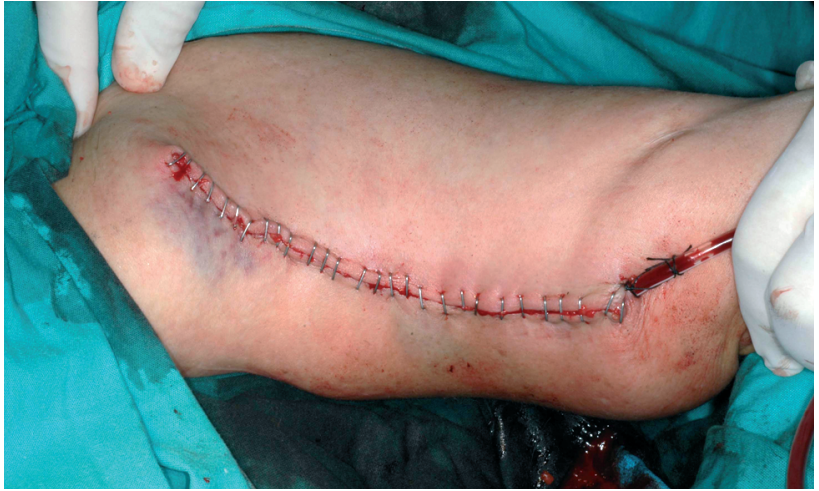

Figura 6. Cierre directo del defecto del brazo. Figure 6. Direct closure of the defect in the arm.
In the patient reported, we did not contemplate the existence of direct cutaneous branches because the predominant vessel was the SCUA, which emitted small branches to the subcutaneous tissue and skin.

In 1992, Matloub et al.4 concluded, based on the dissection of 40 cadavers, that the perfusion of the medial arm derives from a combination of vessels that originate along the course of the brachial que adquiere un papel dominante. Este es en el $95 \%$ de los casos, la ACCS.

Karamursel y colaboradores, ${ }^{5}$ publican en el 2005 la disección de 5 cadáveres y 12 casos clínicos, concluyendo la posibilidad de levantar el colgajo basándose en ramos cutáneos directos en la arteria braquial superficial o en la ACCS la cual estaría presente prácticamente siempre, asegurándose el pedículo del colgajo.

En relación al retorno venoso, los autores, ${ }^{5,6}$ suelen coincidir en la utilización de la vena basílica en caso de que las venas que acompañan a la ACCS no presenten un calibre adecuado para el colgajo, siendo también aptas para ello. Aunque nuestra intención en el caso descrito, era la utilización de la vena basílica, se comprobó que presentaba una ausencia de retorno venoso una vez anastomosada la arteria. Por ello, se utilizó la concomitante de la ACCS, a pesar de la diferencia de calibre con el TVTLF.

El colgajo se puede levantar de igual forma incluyendo los ramos sensitivos cutáneos que provienen del nervio cutáneo braquial medial, aportando de esta forma una cierta sensibilidad a la piel de éste, aunque ello requiere un suplemento en la laboriosidad, y un aumento del tiempo quirúrgico. Por esta razón, este nervio suele seccionarse durante la disección. ${ }^{6}$

Gracias a la elasticidad de la piel de esta localización, se puede obtener un colgajo de aproximadamente unos $8 \mathrm{~cm}$ de anchura sin necesidad de interponer un injerto, procediéndose al cierre directo. Además, el injerto contará con un volumen considerable de tejido subcutáneo (en función del panículo adiposo de cada persona) lo cual es un punto a valorar en las reconstrucciones que precisan mayor volumen de tejido a reponer. En el caso de que precise una mayor anchura, habría que realizar un injerto libre para cubrir el defecto, lo cual se desaconseja ya que el nervio cubital queda bastante desprotegido. En dicho caso habría entonces que optar por la realización de otro tipo de injerto microvascularizado.

Debido a que en ningún caso este tipo de injerto conlleva el sacrificio de una arteria terminal, si durante el transcurso de la cirugía se observara algún tipo de problema en cuanto a la viabilidad del pedículo, tendremos la opción de optar en el mismo acto quirúrgico por cambiar por un colgajo antebraquial. El colgajo de la región medial del brazo, se podrá utilizar entonces como cobertura de piel libre para la reposición antebraquial. El cierre del brazo se realizará de forma directa y el defecto estético será pequeño por tratarse de una zona con buena cicatrización y de localización bastante discreta. artery. Among these vessels, one always has a caliber of more than $1 \mathrm{~mm}$ and is dominant. In 95\% of cases, this vessel is the SCUA.

Karamursel et al.5 in 2005 studied the dissection of 5 cadavers and 12 clinical cases, concluding that a flap can be prepared using direct cutaneous branches of the superficial brachial artery or SCUA, which are almost always present, thus ensuring the pedicle of the flap.

In relation to venous return, authors 5,6 usually agree to use the basilic vein if the veins that accompany the SCUA are not large enough for the flap, because this vein also is suitable. Our intention was to use the basilic vein in the case described, but it was found to lack venous return when the artery was anastomosed. For that reason, the concomitant vein of the SCUA was used despite the difference in caliber with the TLFVT.

The flap can also be prepared by including the cutaneous sensory branches of the medial brachial cutaneous nerve, thus endowing the skin with a certain sensitivity, although it is more time-consuming and prolongs the duration of the intervention. This is why the nerve is usually sectioned during dissection. ${ }^{6}$

Thanks to the elasticity of the skin in this location, a flap approximately $8 \mathrm{~cm}$ wide can be obtained without interposing a graft and the wound can be closed directly. The graft will also have a considerable subcutaneous tissue volume (depending on each person's fatty layer), which is a point to be considered in reconstructions that require more tissue volume for replacement. If more width is needed, a free graft will have to be prepared to cover the defect, which is not advisable because it leaves the ulnar nerve relatively unprotected. In this case, it is necessary to use another type of microvascularized graft.

This type of graft in no case involves sacrificing a terminal artery, so if any problem of pedicle viability is observed in the course of surgery, we have the option of changing to a forearm flap in the same surgical act. The flap of the medial arm can then be used as free skin coverage for replacement with a lower arm flap. The arm is closed directly and the cosmetic defect is small because it is an area with good healing and a discrete location. 


\section{Conclusiones}

Consideramos el injerto libre braquial medial como una opción más a la hora de la reconstrucción de defectos a nivel de cabeza y cuello. Se trata de una alternativa al injerto antebraquial en caso de que se precise un mayor volumen del defecto a tratar y sin dejar a parte otras ventajas como la posibilidad de realizar un cierre directo, el menor defecto estético que se produce, y el no sacrificio de una arteria terminal.

\section{Bibliografía}

1. Urken ML, Cheney ML, Sullivan MJ, Biller HF. Atlas of Regional and Free Flaps for Head and Neck Reconstruction. Raven Pres Ltd, New York 1995;p.p.149-68.

2. Dolmans S, Guinberteau JC, Baudet J. The upper arm flap. J Microsurg 1979;1:1623.

3. Breidenbach WC, Adamson W, Terzis JK. Medial arm flap revisited. Ann Plast Surg 1987; 18:156-63.

4. Matloub HS, Ye Z, Yousif NJ, Sanger JR. The medial arm flap. Ann Plast Surg 1992;29:517-22.

5. Karamürsel S, Bagdath D, Demir Z, Tüccar E, Celebioglu S. Use of medial arm skin as a free flap. J Oral Maxillofac Surg 2005;115:2025-31.

6. Daniel RK, Terzis J, Schwarz G. Neurovascular free flaps: a preliminary report. Plast Reconstr Surg 1975;56:13-20.

7. Matloub HS, Trevisani TT, Eder E, Godina M. The medial arm neurosensory free flap. Presented at the Annual Meeting of the American Society for Plastic and Reconstructive Surgery, New York, NY, October 20, 1981.

\section{Conclusions}

We consider the free medial arm graft to be an option for the reconstruction of defects in the head and neck region. It is an alternative to lower arm grafts if a larger volume defect has to be treated, and it has other advantages like the possibility of performing direct closure, a smaller esthetic defect, and not having to sacrifice a terminal artery. 